\title{
Scientist or Entrepreneur? Identity centrality, university entrepreneurial mission, and academic entrepreneurial intention
}

\author{
Miao Wang ${ }^{1} \cdot$ Danny Soetanto ${ }^{2,3}$ (D) Jianfeng Cai ${ }^{1} \cdot$ Hina Munir ${ }^{4}$
}

Accepted: 12 January 2021 / Published online: 27 January 2021

(c) The Author(s) 2021

\begin{abstract}
The purpose of this study is to examine the relationship between identity centrality and entrepreneurial intention. Based on a survey of 275 academic scientists from 14 Chinese universities, the results show that entrepreneurial identity centrality positively influences the intention to engage in research commercialisation activities, such as spin-off creation, patenting and licensing, contracting research and consulting. We also found that the conflict between entrepreneurial and scientific identity centrality is less problematic than expected in the literature. In fact, the interaction between both identity centralities strengthens academics scientists' intention to involve in academic entrepreneurship. Concerning the influence of institutional factor on academic entrepreneurship, the finding confirms that university entrepreneurial mission moderates the relationship between both identity centralities and the intention to establish spin-offs. Finally, this paper provides insights for academic entrepreneurship in China and practical recommendation for policy makers.
\end{abstract}

Keywords Entrepreneurial intention · Identity centrality · University mission · Academic entrepreneurship

JEL Classification M13 · O31

Danny Soetanto

d.soetanto@lancaster.ac.uk

1 School of Management, Northwestern Polytechnical University, Xi'an 710072, People's Republic of China

2 Department of Entrepreneurship and Strategy, Lancaster University Management School, Lancaster LA1 4YX, UK

3 University of South Australia Business, Adelaide, Australia

4 Division of Arts and Social Sciences, Department of Economics and Business Administration, University of Education, Lahore, Pakistan 


\section{Introduction}

In the last two decades, the policies and governance of many universities have changed with regard to their greater intention and efforts to foster an entrepreneurial climate (Acs et al. 2017; Hayter 2015). Universities are now more entrepreneurial and proactive in transferring their research to society (Abreu and Grinevich 2013; Zhao et al. 2020). Institutional mechanisms, such as technology transfer offices, entrepreneurship curricula, enterprise centres, and university-based incubators, have been created to facilitate the growing interest of universities in entrepreneurial activities (Rasmussen and Wright 2015; Wright et al. 2008 ,2004). While academic entrepreneurship has become a popular subject for scholarly research and policy practice, lacking from this discourse is a deeper understanding of the factors that encourage the main actors-academic scientists- to participate in entrepreneurial activities (O'Kane et al. 2015, 2019, 2020; Würmseher 2017). Being entrepreneurial may offer some advantages, such as improving reputation, higher income, and deriving greater satisfaction (Lam 2010), and an increasing number of academic scientists have thus founded spin-offs as a means to transfer knowledge from the university to marketable products or services (Siegel and Wright 2015). However, compared to the overall population, only few academic scientists commit to spin-off creation, and most tend to remain in their traditional occupational choices as full-time scientists or choose a less entrepreneurial path of knowledge commercialisation, such as patenting, licensing, or consulting (Bercovitz and Feldman 2008; O'Kane et al. 2015; Würmseher 2017).

While universities are increasingly called on to support academic entrepreneurship, they lack understanding of the underlying reasons why their academic scientists choose different research commercialisation paths. Prior studies have predominantly focused on entrepreneurs' attributes, such as risk taking, competences, and social ties, as precursors of entrepreneurship (Scholten et al. 2015; Soetanto and Jack 2016), but overlook the psychological aspect of academic entrepreneurship, that is, how academic scientists' self-concept emerges and affects their intention to pursue entrepreneurial activities (Johnson, Monsen, and MacKenzie 2017; O'Kane et al. 2019; Urban and Chantson 2019). While behavioural models of entrepreneurship have been extensively studied, the relationship between individuals' identity and intention has not been thoroughly examined, especially in the context of academic entrepreneurship (Bercovitz and Feldman 2008; Jain et al. 2009). As intention is deemed not only a bridge between conscious and actual behaviour, but also the proactive commitment to future behaviour (Ajzen 1991, 2002), studying the factors that may influence entrepreneurial intention is crucial in the effort to support academic entrepreneurship (Krueger and Carsrud 1993; Schaltegger and Hörisch 2017).

Being an entrepreneur in an academic setting requires an entrepreneurial mind-set to identify opportunities, organise resources, and create new ventures (Mangematin et al. 2014; Murnieks et al. 2014a; O'Kane et al. 2019; Würmseher 2017). Consequently, academic scientists should build entrepreneurial identity in addition to their scientific identity (Jain et al. 2009). However, simultaneously being an entrepreneur and a scientist may cause conflict in their identity. Although entrepreneurial identity provides academic scientists with the motivation and guidance to identify opportunities and organise resources (Navis and Glynn 2011), it is still not clear whether their initial identity as scientists strengthens or inhibits their participation in research commercialisation activities (O'Kane et al. 2019; Obschonka et al. 2019; Perkmann et al. 2011; Würmseher 2017). While many studies highlight the presence of star scientists or prolific academics in the commercialisation process 
(Lockett et al. 2005), very little is known about their conflicting identity and the impact on their entrepreneurial behaviour.

To fill this gap in the literature, our research intends to address the following questions: How does the entrepreneurial identity of academic scientists influence their intention to undertake research commercialisation activities? Is their participation in academic entrepreneurship strengthened or weakened by their scientific identity? What is the university's role in supporting academic scientists to participate in research commercialisation activities? Similar to previous studies (Abreu and Grinevich 2013; Bercovitz and Feldman 2008; Marzocchi et al. 2019) this study aims to examine the influence of university in understanding the intention of academic scientists to engage in spin-off creation, patenting, licensing, contracting research and consulting. Drawing on identity theory (Fenters et al. 2017), data from 275 academic scientists at Chinese university were analysed at the individual level to reveal the role of entrepreneurial and scientific identity centrality on academic entrepreneurship.

By understanding the role of identity centrality and the influence of organizational context on academic entrepreneurship, this research contributes to the development of knowledge in several ways. First, the study enriches academic entrepreneurship literature by examining the role of self-concept, such as identity centrality and the intention to be involved in different entrepreneurial activities (Perkmann et al. 2013,2011). Second, this study provides unique insights by combining the psychological aspect of academic scientists and external factors, such as the university's mission and policy, as determinant factors of individuals' entrepreneurial intentions. Arguably, this approach provides a better explanation especially on how conflicting factors, such as scientific identity and entrepreneurship policy, may affect academic entrepreneurship. Lastly, this study contributes to the development of empirical research on academic entrepreneurship in China or other countries with a similar context. The findings have implications not only for academic scientists, but also for policy makers seeking insights to develop policies to support academic entrepreneurship.

\section{The conflict of identity centrality: the case of academic entrepreneurship in China}

Academic entrepreneurship as a concept has flourished as a response to the trend that university has becoming increasingly intersected with the commercialization and market orientation of knowledge. A large body of literature has emerged to study the new role of university in economic development which result in the introduction of policies to encourage research commercialization (Foss and Gibson 2015). There are various definitions of academic entrepreneurship, yet there is a lack of agreement about its core component. Following other scholars (Abreu and Grinevich 2013; Bercovitz and Feldman 2008) in defining academic entrepreneurship, this study defines academic entrepreneurship as research commercialization activities involving academic scientists such as researchers, assistant/ associate professor and professor. In commercializing research, academic scientists may take several forms of mechanism spanning from spin-off creation, patenting and licensing, contracting research to consulting. Within this definition, this study excluded students and alumni as the main actor for academic entrepreneurship.

In understanding the factors that motivate academic scientists to become entrepreneurial agents, previous studies have been looking from psychological and personality traits. From 
classic entrepreneurship theories, academic entrepreneurs are similar to other entrepreneurs that are associated with certain characteristics, such as innovation, opportunity recognition, and risk-taking behaviour. Recent studies (Falck et al. 2012; Fenters et al. 2017; Jain et al. 2009) introduce the concept of identity to investigate the underlying mechanism of academic entrepreneurship. Identity theory suggests that a person's self-concept is organised into a hierarchy of role identities that correspond to his/her perceived position in the social structure (Fenters et al. 2017). As a result, individuals may perceive their identity as part of 'their view of self' (Watson 2009). In practice, individuals develop a collection of identities that reflects their role (Stryker 1968; Stryker and Serpe 1994). According to some scholars (Jain et al. 2009; Leavitt et al. 2012), roles and identity differ but are closely related as socially defined elements that underlie a role and the individual's interpretation of such role. Identity as a cognitive concept reflects the identification of individuals' social roles, helps focalise the context and the sense of experience, and guides actual behaviour (Gecas 1982; Thoits 1986).

Another concept in identity theory suggests the differences between identity centrality (Stryker and Serpe 1994) and identity salience (Murnieks et al. 2011; Murnieks, Mosakowski, and Cardon 2014b), two main definitions related to identity hierarchy. Stryker and Serpe (1994) empirically demonstrate that identity centrality and salience are separate but significant predictors of behaviour. The key distinction is that identity centrality reflects the relative importance of the focal identity in one's own self-concept, which is more likely associated with autonomous behavioural decisions (Murnieks, Mosakowski, and Cardon 2014b), while identity salience is the extent of an individual's readiness to act out a target identity (Gecas 1982; Stryker and Serpe 1994). As such, we can assume that the relation between identity centrality and behavioural intention is more significant than that of identity salience, and this relation is likely to provide a powerful explanation in the entrepreneurial or academic entrepreneurial domain. Thus, we consider the influence of identity centrality rather than identity salience as the main factor of activating entrepreneurial behaviour.

Academic scientists with entrepreneurial identity centrality are more inclined to commercialise their research and attempt to acquire idiosyncratic knowledge that better enables them to recognise opportunities (Etzkowitz et al. 2000). Similarly, scientific identity centrality refers to the perceptions of academic scientists in mirroring the behaviour of scientists. However, the literature remains inconclusive on how academic scientists deal with both two identity centralities (Mangematin et al. 2014). As a scientific mind set is often deemed incompatible with an entrepreneurial mind set (Jain et al. 2009), they often struggle with the decision to pursue research or commercial interests (Bartunek and Rynes 2014; Nelson 2014). On many occasions, they face the dilemma of whether to remain in academia or become entrepreneurs (Bercovitz and Feldman 2008; Castillo Holley and Watson 2017; Vohora et al. 2004). Consider the daily routine of academic scientists where they may spend the majority of their days at the university as a lecturer or scientist, they are more familiar with non-commercial university environment and their scientific identity centrality is clearly explicitly manifested in their teaching and research activities. On other occasions, they may act as entrepreneurs performing managerial tasks and making decisions, albeit with less certainty. If asking the individual to describe what defines him/ her as an entrepreneur or a scientist, or what is most important to them, he/she may struggle to answer. This is because both identity centralities are simultaneously highly relevant. 


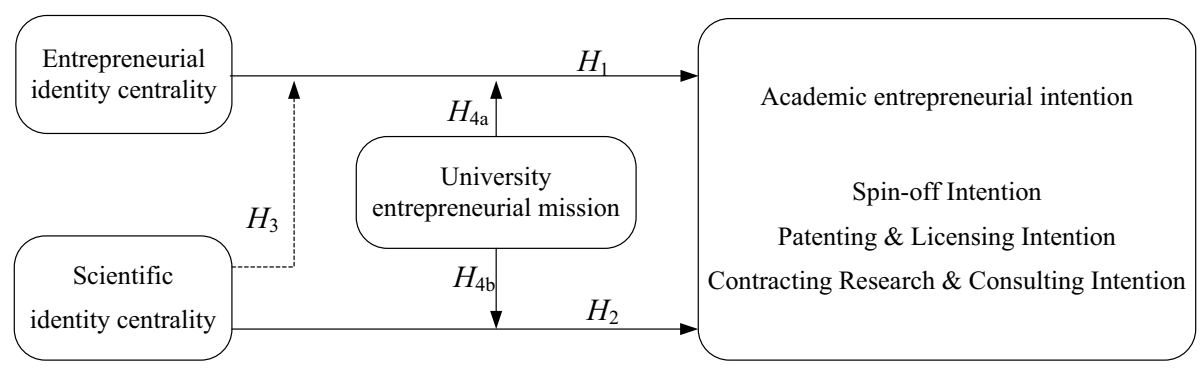

Fig. 1 Research framework

While combined identities will simultaneously influence individuals' behaviours (Ashforth 2000). This study seeks to examine whatever such combination reinforces or weakens the outcome on academic entrepreneurship.

\section{Hypotheses development}

This study aims to examine the role of identity centrality in influencing academic scientists' intention to commercialise research in Chinese context. In recent years, universities in China have witnessed a significant change in relation to their expected roles to drive economic growth and competitiveness through technology transfer and research commercialisation (Wu et al. 2017; Wu 2010). ${ }^{1}$ To support this initiative, the Chinese government have invested a large-scale national programme to promote technology transfer (Chen et al. 2016; Liu and Huang 2018), and to position universities at the centre of national innovation system (J. Wu, Zhuo, and Wu 2017). As the performance of research commercialization and academic entrepreneurship in China has increased significantly in recent years (Chen, Patton, and Kenney 2016), ${ }^{2}$ there is an urgent need to understand the nature of academic entrepreneurship especially factors that encourage academic scientists to commercialize their knowledge and research.

Literature on academic entrepreneurship has been extensively studied the behavioural models of entrepreneurship (Jain et al. 2009). However, the relationship between identity and intention has not been thoroughly examined, especially in the context of academic entrepreneurship in China. As intention is deemed not only a bridge between conscious and actual behaviour, but also the proactive commitment to future behaviour (Krueger et al. 2000), studying the factors that may influence entrepreneurial intention is crucial especially

\footnotetext{
1 The governance of research commercialization at Chinese universities has significantly improved. More universities has strengthened the reward system and created professional TTOs. At the end of 2018, more than 500 academic organizations set up TTOs, rising $92.8 \%$ over 2017 (the number is from "Technology Transfer Report" issued by Chinese National Centre for S \& T Evaluation in 2019).

2 According to the Technology Transfer Report (2018) and the Compilation of Statistical Resources of S \& $\mathrm{T}$ for Colleges and Universities (2017) issued by Chinese Ministry of Education, the number of patent authorization was climbed to 144 thousand, selling with 2.2 billion CNY; The revenue of university-industry contract research is account for 12.1 billion $\mathrm{CNY}$; The number of registered academic scientists who are involved in university spin-off companies is over 21 hundred, and the amount of cash stock awards for individual academic scientists' engagement is up to 4700 million CNY.
} 
in the effort to support academic entrepreneurship (Krueger and Carsrud 1993; Schaltegger and Hörisch 2017).

The study contributes to the current debate in the literature by empirically studying both entrepreneurial identity centrality and scientific identity centrality (H1 and H2). The next hypothesis was constructed as a response to the previously discuss conflict of dilemma (H3). The last hypothesis ( $\mathrm{H} 4 \mathrm{a}$ and $\mathrm{H} 4 \mathrm{~b}$ ) tests the influence of institutional factors, as we believe that context and policies might have an impact on academic scientists' intention to be actively participate in research commercialisation. To illustrate our research framework, Fig. 1 shows the hypotheses constructed for this study.

\subsection{Entrepreneurial identity centrality and entrepreneurial intention}

Several scholars (Huyghe et al. 2016; Ibarra 1999) argue that individuals' identity centrality motivates their intention and their actual behaviour. In the context of academic entrepreneurship, some studies (Jain et al. 2009; Murnieks et al. 2014a) find that the identity centrality of academic scientists involved in entrepreneurial activities influences the way in which they recognise and exploit opportunities from research and knowledge developed at the university (Mathias and Williams 2017). It has been argued that entrepreneurial identity centrality encourages academic scientists to be more active in entrepreneurial activities through accumulating competences for commercialising research, and guiding behaviour to engage in academic entrepreneurship activities (Falck et al. 2012). Likewise, Murnieks et al. $(2014 \mathrm{a}, \mathrm{b})$ find that entrepreneurs' passion is also influenced by their entrepreneurial identity. Thus, we propose that academic scientists with entrepreneurial identity centrality are more likely to think about establishing spin-offs as a way to commercialise research. In this case, their entrepreneurial identity centrality allows those academic scientists to take risk and deal with uncertainty in starting a new business.

However, compared with establishing spin-offs, other types of research commercialisation activities such as consulting, contracting research, patenting and licensing are less risky and only needs little engagement. Those activities require less entrepreneurial skills and commitments. Consequently, we expect that entrepreneurial identity centrality has little effect on academic scientists' intention to patenting, licensing and contracting research. To summarise, the following hypothesis was constructed.

H1 Academic entrepreneurial identity centrality has significant and positive influence on the intention for spin-off creation but has less significant and negative influence on the intention for patenting/licensing and for contracting research and consulting intention.

\subsection{Scientific identity centrality and entrepreneurial intention}

The next hypothesis deals with the distinctive effect of scientific identity centrality on entrepreneurial intention. According to Ibarra (1999), entrepreneurship is a process of transformation from an old identity to a new identity. However, this process might not happen entirely in the context of academic entrepreneurship, often retaining their identity as academic scientists. Compared with other traditional forms of entrepreneurship, individuals who engage in academic entrepreneurship usually still work at the university and contribute to research activities. In such case, they may still retain a scientific mind-set and act according to scientific norms (Lam 2010; Siegel and Wright 2015). If participation in entrepreneurial activities involves performing roles that an entrepreneurial identity 
imposes on them and then incorporating these into their persona, enacting these two-role identity centralities may create conflict, as they are often viewed as opposing. As a result, the effects of scientific identity centrality may be diverse on different academic entrepreneurial activities.

For creating spin-off companies, some studies find a negative relationship between scientific identity centrality and creating companies (Jain et al. 2009). Scientific identity centrality may guide academic scientists to focus on their research and overlook their desire to creating university spin-offs. In the scientific world, the notion of universality and the communism of scientific ethos are often in conflict with an entrepreneur's belief in the need to develop a unique product and technology as private property in a capitalist economy. The conflict identities are shaped by distinct social norms among academia and industry, as well as the personal interests of academic scientists, which will influence their behaviour (Dunn and Jones 2010; Hirsh and Kang 2016). There is an obvious battle between the applied and speedy attitude in a business environment and the fundamental and careful attitude in academic research ( $\mathrm{Wu} 2010)$.

Regarding to patenting and licensing, some studies emphasized that academic scientists' decision to patent their research is associated with is their perceived benefits and costs of patent protection (Owen-Smith and Powell 2001). Given that patenting is only depend on the research findings, and licensing utilizes the marketing mechanisms, individual scientists who engage in patenting and licensing will not disrupt their scientific research, on the contrary these activities may consolidate their scientific identity centralities (Wu et al. 2017). In such case, individual with higher scientific identity centrality will enhance the likelihood of engage in patenting and licensing.

For contracting research and consulting activities, we can apply a similar argument. as we known from (Fernández-Pérez et al. 2015; Zhao et al. 2020), contracting research and consulting activities are largely affected by social networking, academic scientists with higher scientific identity centrality usually make their effort to build up personal social networks and engage in contracting research and consulting activities. In this case, the conflict of social norms between academia and industry will not play a lead role. Thus, we propose the following hypothesis:

H2 Scientific identity centrality is positively related to patenting and licensing intention and contracting research and consulting intention but negatively related to spin-off intention.

\subsection{The interaction between entrepreneurial and scientific identity centrality and its impact on entrepreneurial intention}

While the previous hypotheses argue that both entrepreneurial and scientific identity centrality may have different influence on different academic entrepreneurial intentions, we argue that in China, both identity centrality can co-exist and strengthen the intention to engage in entrepreneurial activities. As the universities put a high value on scientific discovery and provide rewards for conducting entrepreneurial activities, the new generation of academic scientists in China start to accept the importance of conducting and commercialising research. As a result, entrepreneurial and scientific identity centrality can co-exist and strengthen the intention to engage in entrepreneurial activities. Academic scientists may develop new entrepreneurial identity centrality as well as old scientific identity centrality (Fenters et al. 2017; Lam 2010). In this case, one identity may not constrain the effects 
of other identities, but these identities are reinforced or complementary (Ashforth 2000). Given this point of view, we argue that if there is no conflict between scientific identity centrality and entrepreneurial identity centrality, both identities can simultaneously promote the formation of academic entrepreneurship intention (Abreu and Grinevich 2013, 2017). According to prior literature, academic entrepreneurship is essentially derived from scientific research and may provide opportunities to accumulate individual social welfare, financial rewards, reputation, and prestige, further successfully reinforcing commercialisation behaviour (Abreu and Grinevich 2013; Perkmann et al. 2013) Scientific identity centrality may also create new possibilities for scholars, including transferring the university technology thanks to their scientific reputation (Henkel 2005). As a result, scientific identity centrality may strengthen the relationship between entrepreneurial centrality and intention to perform entrepreneurial activities. Thus, we propose:

H3 Scientific identity centrality moderates the relationship between entrepreneurial identity centrality and academic entrepreneurial intentions. In this case, the interaction between both entrepreneurial and scientific identity centrality has positive influence for spin-off intention, patenting and licensing intention, contracting research and consulting intention.

\subsection{The interaction between University entrepreneurial mission and Identity Centrality}

The next hypothesis draws on institutional, suggesting that the institutional context may have an effect on individual behaviour. As the organisational mission reflects the institutional beliefs, values, and the code of conduct for individuals' actions in the organisation (Klemm et al. 1991) universities with an entrepreneurial mission emphasise the importance of entrepreneurial activities and research commercialisation besides the traditional teaching and research roles (Ambos et al. 2008; Etzkowitz et al. 2000). We argue that university missions that support the creation of entrepreneurial activities have a direct effect on the intention to be active in commercialisation activities through the construction of support mechanisms, such as a technology transfer office, facilities such as incubators, and incentives for engaging in knowledge transfer activities. Empirical evidence shows a positive relation between universities with a strong entrepreneurial mission and their academic entrepreneurship (Huyghe et al. 2015). Other studies find that the knowledge transfer activity flourishes at universities with an entrepreneurial culture (Iorio et al. 2017). Overall, those policies open the way for new opportunities and encourage academic scientists to be more entrepreneurial.

This study argues that the university's policy and culture provide a strong incentive for academic entrepreneurship as it reflects university institutional context. As the literature suggests that context may influence how individuals think and plan (Farmer et al. 2003), we propose that the university entrepreneurial mission strengthens the effect of entrepreneurial identity centrality on entrepreneurial intention. Universities that emphasise the importance of entrepreneurship and research commercialisation provide a favourable entrepreneurial context that may influence academic scientists' attitude to balance their role identities in the identity hierarchy (Sá et al. 2018), and promote the positive effect of academic entrepreneurial centrality on the intention to participate in research commercialisation activities. As a result, academic scientists are more likely to engage in entrepreneurial activities when perceiving better resources, greater support, and a more conducive environment. 
H4a University entrepreneurial mission reinforces the positive relationship between academic entrepreneurial identity centrality and spin-off intention and weakened the negative relationship between academic entrepreneurial identity centrality and patenting and licensing intention; contracting research and consulting intention.

With regard to scientific identity centrality, universities with a strong entrepreneurial mission may weaken the negative effect on spin-off intention and strengthen the positive effect on patenting and licensing intention and on contracting research and consulting intention. As universities encourage entrepreneurial activities among their academic staff by providing support, regulation, and incentives, academic scientists may be open to a new alternative career and become more sensitive to exploring opportunities to engage in academic entrepreneurship (Hayter et al. 2018). Consequently, the negative effect of scientific identity that may hinder research commercialisation activities among academic scientists may reduce, and the positive effect of scientific identity may go up. Based on the above arguments, we propose the following hypotheses:

H4b University entrepreneurial mission reinforces the positive relationship between academic scientific identity centrality and patenting and licensing intention; contracting research and consulting intention and weakened the negative relationship between academic entrepreneurial identity centrality and spin-offs intention.

\section{Research method}

\subsection{Research approach}

This study aims to investigate how entrepreneurial and scientific identity centrality influence the intention to engage in academic entrepreneurship. By focusing at individual level, this study has followed previous studies in exploring the role of individual traits and characteristics such as motivations (Hayter 2015; Lam 2010), passions (Huyghe et al. 2016), cognitions (Urban and Chantson 2019), and identity (Fenters et al. 2017; Jain et al. 2009). However, as literature has also highlighted the role of context in influencing individual's behavioural decision-making such as academic department (Rasmussen and Wright 2015), university's policies (Huyghe et al. 2015), and industrial characteristics (Abreu and Grinevich 2013). This study examine the role of university entrepreneurial mission on moderating the relationship between identity centrality and entrepreneurial intention of academic scientists. By combining both factors, this study provides a deeper understanding on how entrepreneurial and scientific identity centrality determine the intention to choose a certain pathway for commercialization in the context where university's entrepreneurial support is present or absent.

\subsection{Sampling and data collection}

Given the fact that only a few elite universities in China receive funding to promote academic entrepreneurship, academic scientists from common universities have less opportunities to engage in academic entrepreneurship (Wu 2010; Wu et al. 2017). For that reason, the sample of our research mainly focus on elite universities, which may have high 


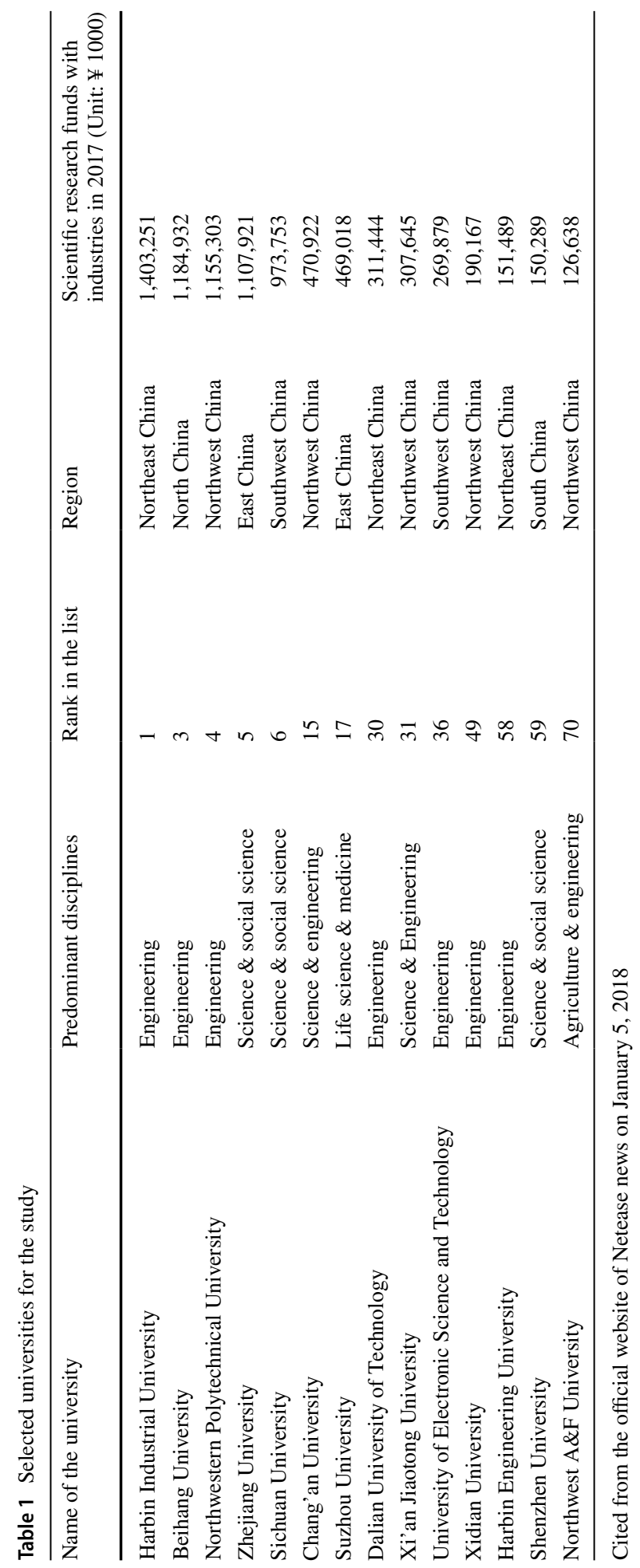


Table 2 The description of sample in the study

\begin{tabular}{llr}
\hline Categories & & Frequency \\
\hline Gender & Male & 196 \\
& Female & 78 \\
Age & Under 30 & 17 \\
& $30-39$ years & 129 \\
& $40-49$ years & 80 \\
Academic position & 50 and over & 49 \\
\multirow{5}{*}{ Discipline } & Assistant Professor or Lecturer & 70 \\
& Associate Professor or Professor & 205 \\
& Basic sciences (physics, chemistry, etc.) & 27 \\
Previous commercialization & 25 \\
experience & Life sciences including biology and agriculture & 137 \\
& Engineering & 86 \\
& Humanities and social sciences & 26 \\
& Spin-off & 148 \\
& Patenting and licensing & 199 \\
& Contract research, consulting & 13 \\
\hline
\end{tabular}

potential for transferring knowledge and technology to market. Based on the list of the top 100 universities in the development of technology and science published by the Chinese Ministry of Education. This study selected 14 universities (Table 1) that follow several criteria such as representing universities from different region in China, covering various disciplines and subjects as well as engaging in industrial research as shown from the research fund received from the industry.

Before launching the survey, we conducted a pilot survey with a sample of 78 researchers who are familiar with or have experience in research commercialization from the Northwestern Polytechnical University in Xi'an. After receiving feedback, some questionnaire items were revised to increase clarity. Most of the revisions were related to the un-clarity and ambiguities of the questions because of direct translation from the original survey questions. Using Matlab's data-crawled technology, the email addresses were gathered from the official websites of selected universities. Due to wrong addresses or failing to connect to the mailbox service, 564 addresses were eliminated from our initial website dataset. The data collection process (survey) was conducted from March to June 2018 targeting academic scientists (note: $\mathrm{PhD}$ students were excluded). To ensure the validity of the survey and the representativeness of the sample, we sent random emails to 20 respondents in one department, if there was no response after 3 days, another 20 respondents were required until we obtained 5 responses from one department or all respondents in the same department were invited (Podsakoff and Organ 1986). In total, the invitation to participate in the survey was sent to 2,384 academic scientists. We received a total 364 responses of which 275 were considered valid.

T-test was carried out to test the validity of collected data. The final data shows no significant difference $(p>0.5)$ between respondents who compiled all the questions and those who compiled the questionnaire with inadequate responses, or between early or late respondents 
of different gender, age, seniority and discipline. Among 275 respondents of this study, 196 of them are males. The sample also covers a wide range of academic scientists from different ages, in which the majority (129 respondents) ages are between 30-39 years old. In addition, 205 respondents are professors or associated professors, and the majority of the samples have engineering (137 respondents) and humanity/social sciences background (86 respondents). In terms of previous commercialization experience, only 26 respondents suggested a spin-off experience, while 199 respondents had informal commercialization experience- contracting research and consulting (Table 2).

\subsection{Variable and measurement}

\subsubsection{Dependent variables}

Following recent studies on entrepreneurship (Douglas and Fitzsimmons 2013; Huyghe et al. 2015; Johnson et al. 2017) we measured academic entrepreneurial intention as individuals' intention to conduct the following activities: (i) founding a university spin-off; (ii) patenting or licensing; (iii) commercialising the research through contracting research and consulting. The variables "spin-off intention", "patenting and licensing intention", and "contracting research and consulting intention" were created based on scales used in prior literature (Douglas and Fitzsimmons 2013; Huyghe et al. 2015). However, we made some adaptations to meet the special institutional context in China. We calculated these variables through the weighted average values of each item given by respondents, and the weight was determined by the factor loadings from the exploratory factor analysis (EFA). All three items were associated with a 5 -point Likert-type scale ranging from " $1=$ strongly disagree" to " $5=$ strongly agree".

Spin-off Intention (SOI) Drawing on the actual definition of academic spin-offs (Iacobucci and Micozzi 2015) and the entrepreneurship intention scales in Krueger et al. (2000), we measured spin-off intention with three items. The respondents were asked: "How likely is it that in the foreseeable years you will engage in: (1) founding a company with research partners; (2) founding a company based on university scientific research findings; (3) founding a company to commercialise your scientific research at university".

Patenting and Licensing Intention (PLI) Considering the broad definition of academic entrepreneurship (Abreu and Grinevich 2013), we measured patenting and licensing intention by asking respondents the following questions: "How likely is it that in the foreseeable years you will: (1) apply for patents for your research findings and new inventions at the university; (2) license part of your scientific research to industry by assigning technology or becoming a shareholder in a company; (3) be awarded intellectual property rights (IPRs, e.g., patents, copyrights, and trademarks).

Contracting Research and Consulting Intention (CCI) Based on prior entrepreneurship studies (Johnson et al. 2017), we measured contracting research and consulting intention with the following questions: "How likely is it that in the foreseeable years you will engage in: (1) collaborative research with industry; (2) contract research with industry; (3) technical consulting or management consulting.

\subsubsection{Independent variables}

We created two variables "entrepreneurial identity centrality" and "scientific identity centrality" to measure the importance of individual's sense of belonging to a specific identity 
in the identity hierarchy. We constructed the measurement for these variables using the identity centrality scale developed by Sellers et al. (1997). We deleted all the reverseworded items as mixed-worded measures are problematic for the Chinese culture and cause some translation issues with cross-cultural research (Wong et al. 2003). Moreover, we defined each variable by calculating the weighted average values of each item given by respondents. The weight was determined by the factor loadings from the EFA. All the items were associated with a 5-point Likert-type scale ranging from " $1=$ strongly disagree" to " $5=$ strongly agree".

Entrepreneurial Identity Centrality (EIC) Drawing on the studies (Falck et al. 2012; Jain et al. 2009), we measured entrepreneurial identity centrality with the following questions: "To what extent do you agree with the following statements: (1) Overall, commercialising your research to industry will be an important part of your self-image; (2) Your destiny is tied to the destiny of other academic entrepreneurs; (3) You have a strong sense of commercialising your research to industry; (4) You have a strong attachment to scholars who commercialise their research to industry; (5) Commercialising your research to industry will be an important reflection of who you are".

Scientific Identity Centrality (SIC) Based on studies on the role of identities in the academic setting (Perkmann et al. 2013), we measured scientific identity centrality by asking participants the following questions: "To what extent do you agree with the following statements: (1) Overall, being an academic scientist is an important part of your self-image; (2) Your destiny is tied to the destiny of other academic scientists; (3) You have a strong sense of being an academic scientist; (4) You have a strong attachment to academic scientists who are passionate about their research; (5) Being an academic scientist is an important reflection of who you are".

\subsubsection{Moderating variable}

University Entrepreneurial Mission (UEM) Following previous studies (Huyghe et al. 2015), we measure university entrepreneurial mission, we asked the following questions: "To what extent does your university focus on the following missions: (1) encouraging scientific research with practical implications; (2) paying more attention to university technology transfer (e.g., patents, licenses, spin-offs); (3) creating an entrepreneurial culture; (4) cultivating innovative skills; (5) encouraging contract research and consulting with industry". We created this variable through calculating the weighted average values of each item given by respondents, and the weight was determined by the factor loadings from the EFA. All the items were associated with a 5-point Likert-type scale ranging from " $1=$ strongly disagree" to " $5=$ strongly agree".

\subsubsection{Control variables}

Gender (GEN) As we expect a potential difference in terms of entrepreneurial behaviour between men and women (Abreu and Grinevich 2013; Ding et al. 2013; Goel et al. 2015), we included the gender variable as a control variable using a dummy variable where " $0=$ male" and " $1=$ female".

Seniority ( $S E N)$ We measured seniority with a dummy variable as " $0=$ assistant professor or lecturer" " $1=$ associate professor or professor". We controlled this factor for its positive effects on research commercialisation (Perkmann et al. 2013). 
Scientific discipline (SCD) Some studies (e.g., Perkmann et al. 2011) find that academic scientists in some disciplines may have a stronger propensity to engage in research commercialisation than others, and as such, we expect that disciplines such as science and engineering are more active in research commercialisation activities than the humanities and social sciences. Referred the standard classification of disciplines from Chinese MOE, we measured scientific discipline with four dummy variables: (1) science $(S C I)$; (2) life science, agriculture, and medicine ( $L A M)$; (3) engineering (ENG); (4) humanities and social sciences $(H S)$, each coded as " $1=$ affiliated" and " $0=$ not affiliated".

Previous commercialisation experience (PCE) We expect that previous experience in commercialising research will influence academic scientists' entrepreneurial behaviour (Clarysse et al. 2011; Scholten et al. 2015), and thus employed a dummy variable coded as " $0=$ no" and " $1=$ yes" indicating whether the respondent had previously engaged in academic entrepreneurship.

\subsection{Data analysis}

Table 3 shows the mean, standard deviation, and correlations of each variable. The sample is composed of 275 academics in Chinese universities including $28.4 \%$ female and $74.5 \%$ (associate) professors, $74.0 \%$ have commercialisation experience. Additionally, the multiple correlations in correlation matrix preliminarily shows the multicollinearity between the different variables may not be high enough to influence the results of regression. Even so, the relatively lower correlations do not indicate no multicollinearity, and the calculation of the variance inflation factor (VIF) or Tolerance is needed.

Considering that all the data is self-reported, the results could be vulnerable to common method bias (CMB) (Podsakoff et al. 2003). To reduce the risk of CMB, we implemented a rigorous statistical approach to verify the reliability and validity of the measures. First, we used Harman's one-factor test to check for obvious CMB that interfered with the results. The test aimed to identify any covariance of single factors accounting for the majority (50\%) among all the items (Podsakoff et al. 2012). After executing a principal component analysis, the result indicate that the largest component represents only $31.678 \%$ of all items, thus there is no evidence of CMB affecting the results. Second, we performed a reliability analysis and the results in Table 4 show that the Cronbach's alpha of all the scales is above 0.8 , indicating good reliability. Then, the item-total correlations of each variable additionally demonstrate reliability. Furthermore, we employed a confirmatory factor analysis (CFA) to test the convergent validity and discriminant validity of each scale through AMOS 22. As seen in Table 4, the results show that the standardised regression weight of all items is over 0.5, the average variance extracted (AVE) and composite reliability (CR) of variables are beyond 0.5 and 0.7 respectively, representing good convergent validity (Fornell and Larcker 1981). Moreover, for single variables, the square root of AVE is greater than the corresponding correlations with all the other variables. As such, discriminant validity is confirmed (Farrell 2010). 


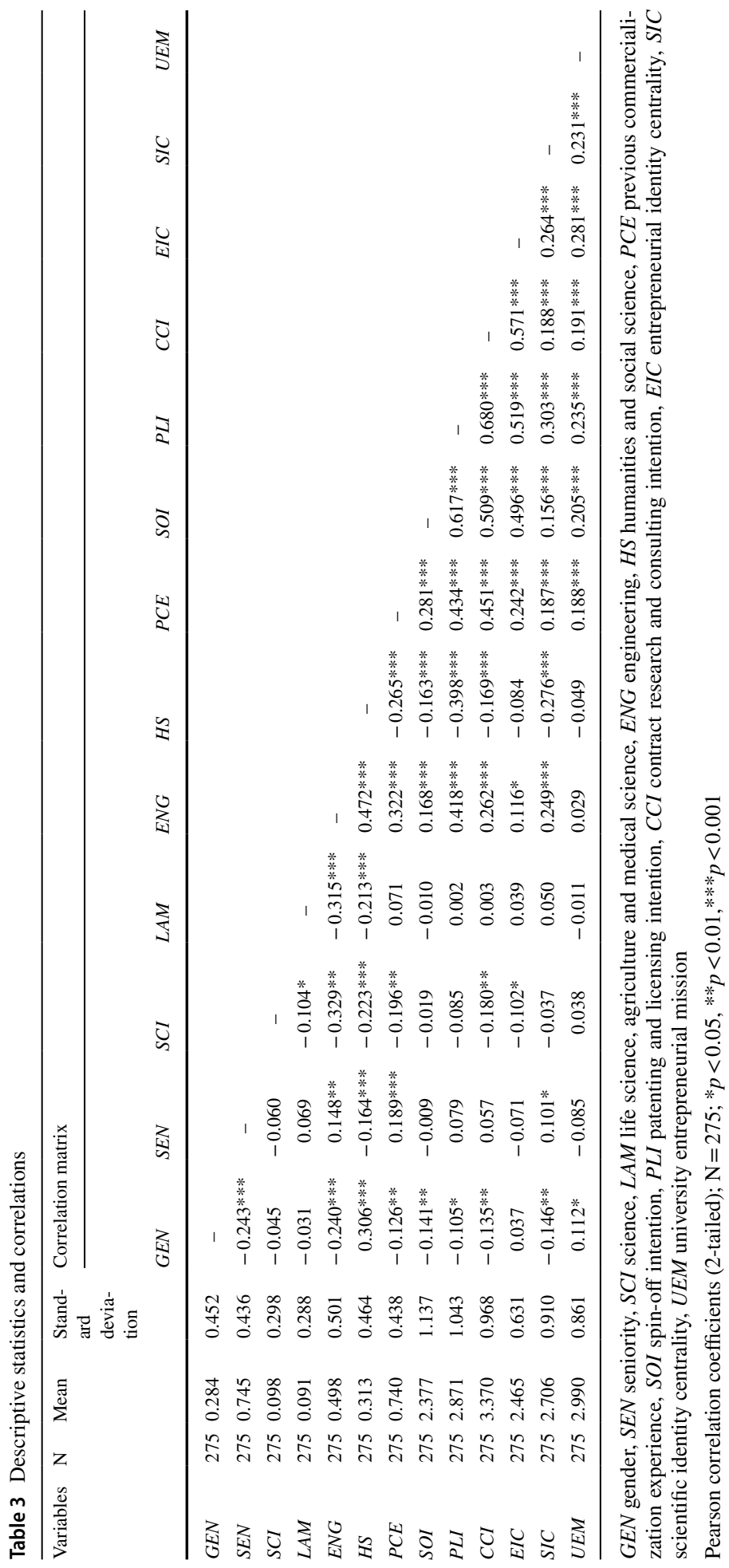


Table 4 Reliability and validity analysis

\begin{tabular}{|c|c|c|c|c|c|c|c|}
\hline \multirow[t]{2}{*}{ Variables } & \multirow[t]{2}{*}{ Variables items } & \multirow{2}{*}{$\begin{array}{l}\text { Factorial } \\
\text { analysis }\end{array}$} & \multicolumn{2}{|l|}{ Reliability } & \multicolumn{3}{|l|}{ Validity } \\
\hline & & & $\begin{array}{l}\text { Cronbach's } \\
\text { alpha }\end{array}$ & $\begin{array}{l}\text { Item-total } \\
\text { correlations }\end{array}$ & $\begin{array}{l}\text { Standardized } \\
\text { regression } \\
\text { weights }\end{array}$ & AVE & $\mathrm{CR}$ \\
\hline \multirow[t]{5}{*}{ EIC } & E1 & $\begin{array}{l}\text { KMO } \\
0.867 \\
\chi^{2} 851.936 \\
\text { Sig. } * * *\end{array}$ & 0.900 & 0.757 & 0.812 & 0.650 & 0.902 \\
\hline & $E 2$ & & & 0.821 & 0.891 & & \\
\hline & E3 & & & 0.807 & 0.840 & & \\
\hline & $E 4$ & & & 0.751 & 0.812 & & \\
\hline & E5 & & & 0.630 & 0.657 & & \\
\hline \multirow[t]{5}{*}{ SIC } & $S 1$ & $\begin{array}{l}\text { KMO } \\
0.882 \\
\chi^{2} 1338.128 \\
\text { Sig. } * * *\end{array}$ & 0.939 & 0.717 & 0.721 & 0.765 & 0.942 \\
\hline & $S 2$ & & & 0.877 & 0.884 & & \\
\hline & $S 3$ & & & 0.858 & 0.893 & & \\
\hline & $S 4$ & & & 0.839 & 0.900 & & \\
\hline & S5 & & & 0.905 & 0.957 & & \\
\hline \multirow[t]{5}{*}{$U E M$} & $U M 1$ & $\begin{array}{l}\text { KMO } \\
0.790 \\
\chi^{2} 511.457 \\
\text { Sig. } * * *\end{array}$ & 0.859 & 0.689 & 0.772 & 0.701 & 0.921 \\
\hline & $U M 2$ & & & 0.776 & 0.883 & & \\
\hline & $U M 3$ & & & 0.721 & 0.780 & & \\
\hline & UM4 & & & 0.633 & 0.671 & & \\
\hline & UM5 & & & 0.747 & 0.775 & & \\
\hline \multirow[t]{3}{*}{ SOI } & $\mathrm{SO1}$ & $\begin{array}{l}\text { KMO } \\
0.731 \\
\chi^{2} 834.319 \\
\text { Sig. } * * *\end{array}$ & 0.940 & 0.808 & 0.823 & 0.847 & 0.943 \\
\hline & $\mathrm{SO} 2$ & & & 0.907 & 0.961 & & \\
\hline & $\mathrm{SO} 3$ & & & 0.913 & 0.969 & & \\
\hline \multirow[t]{3}{*}{$P L I$} & $P L 1$ & $\begin{array}{l}\text { KMO } \\
0.752 \\
\chi^{2} 517.145 \\
\text { Sig. } * * *\end{array}$ & 0.901 & 0.821 & 0.892 & 0.755 & 0.902 \\
\hline & $P L 2$ & & & 0.807 & 0.870 & & \\
\hline & PL3 & & & 0.790 & 0.844 & & \\
\hline \multirow[t]{3}{*}{$C C I$} & $C C 1$ & $\begin{array}{l}\text { KMO } \\
0.717 \\
\chi^{2} 830.179 \\
\text { Sig. } * * *\end{array}$ & 0.941 & 0.854 & 0.881 & 0.856 & 0.947 \\
\hline & $C C 2$ & & & 0.859 & 0.892 & & \\
\hline & $C C 3$ & & & 0.633 & 0.998 & & \\
\hline
\end{tabular}

EIC entrepreneurial identity centrality, SIC scientific identity centrality, UEM university entrepreneurial mission, SOI spin-off intention, $P L I$ patenting and licensing intention, $C C I$ contract research and consulting intention

$\mathrm{N}=275 ; * p<0.05, * * p<0.01, * * * p<0.001$ 
Table 5 Regression results with spin-off intention as a dependent variable

\begin{tabular}{|c|c|c|c|c|c|}
\hline Variables & Model 1 & Model 2 & Model3 & Model 4 & Model 5 \\
\hline$G E N$ & $\begin{array}{l}-0.266^{*} \\
(0.156)\end{array}$ & $\begin{array}{l}-0.336^{* *} \\
(0.139)\end{array}$ & $\begin{array}{l}-0.339 * * \\
(0.140)\end{array}$ & $\begin{array}{l}-0.362 * * \\
(0.141)\end{array}$ & $\begin{array}{l}-0.372^{* * * *} \\
(0.140)\end{array}$ \\
\hline SEN & $\begin{array}{l}-0.252 \\
(0.158)\end{array}$ & $\begin{array}{l}-0.106 \\
(0.142)\end{array}$ & $\begin{array}{l}-0.105 \\
(0.141)\end{array}$ & $\begin{array}{l}-0.092 \\
(0.142)\end{array}$ & $\begin{array}{l}-0.118 \\
(0.142)\end{array}$ \\
\hline$S C I$ & $\begin{array}{l}0.169 \\
(0.308)\end{array}$ & $\begin{array}{l}0.314 \\
(0.274)\end{array}$ & $\begin{array}{l}0.306 \\
(0.276)\end{array}$ & $\begin{array}{l}0.247 \\
(0.278)\end{array}$ & $\begin{array}{l}0.279 \\
(0.274)\end{array}$ \\
\hline$L A M$ & Omitted & Omitted & Omitted & Omitted & Omitted \\
\hline$E N G$ & $\begin{array}{l}0.172 * \\
(0.099)\end{array}$ & $\begin{array}{l}0.191^{*} \\
(0.100)\end{array}$ & $\begin{array}{l}0.188^{*} \\
(0.102)\end{array}$ & $\begin{array}{l}0.162 * \\
(0.094)\end{array}$ & $\begin{array}{l}0.189 * \\
(0.099)\end{array}$ \\
\hline$H S$ & $\begin{array}{l}-0.035 \\
(0.254)\end{array}$ & $\begin{array}{l}0.052 \\
(0.227)\end{array}$ & $\begin{array}{l}0.050 \\
(0.228)\end{array}$ & $\begin{array}{l}0.027 \\
(0.228)\end{array}$ & $\begin{array}{l}0.024 \\
(0.227)\end{array}$ \\
\hline$P C E$ & $\begin{array}{l}0.692 * * * \\
(0.163)\end{array}$ & $\begin{array}{l}0.412 * * * \\
(0.149)\end{array}$ & $\begin{array}{l}0.407 * * * \\
(0.150)\end{array}$ & $\begin{array}{l}0.388 * * \\
(0.151)\end{array}$ & $\begin{array}{l}0.378 * * * \\
(0.149)\end{array}$ \\
\hline$E I C$ & & $\begin{array}{l}0.840 * * * \\
(0.099)\end{array}$ & $\begin{array}{l}0.774 * * * \\
(0.261)\end{array}$ & $\begin{array}{l}0.593 * * \\
(0.278)\end{array}$ & $\begin{array}{l}0.815 * * * \\
(0.101)\end{array}$ \\
\hline$S I C$ & & $\begin{array}{l}-0.229 * * \\
(0.108)\end{array}$ & $\begin{array}{l}-0.145^{*} \\
(0.083)\end{array}$ & $\begin{array}{l}-0.174 * * \\
(0.084)\end{array}$ & $\begin{array}{l}-0.175^{*} \\
(0.104)\end{array}$ \\
\hline$U E M$ & & & & $\begin{array}{l}0.416 * * \\
(0.213)\end{array}$ & $\begin{array}{l}0.430 * * \\
(0.209)\end{array}$ \\
\hline$E I C * S I C$ & & & $\begin{array}{l}0.263 * * \\
(0.120)\end{array}$ & & \\
\hline$E I C^{*} U E M$ & & & & $\begin{array}{l}0.186^{*} \\
(0.109)\end{array}$ & \\
\hline$S I C * U E M$ & & & & & $\begin{array}{l}0.127 * \\
(0.073)\end{array}$ \\
\hline Constant & $\begin{array}{l}2.035 * * * \\
(0.288)\end{array}$ & $\begin{array}{l}3.112 * * \\
(1.353)\end{array}$ & $\begin{array}{l}2.281 * * \\
(0.946)\end{array}$ & $\begin{array}{l}0.542^{*} \\
(0.299)\end{array}$ & $\begin{array}{l}0.536 * \\
(0.285)\end{array}$ \\
\hline $\mathrm{R}^{2}$ & 0.105 & 0.277 & 0.300 & 0.305 & 0.301 \\
\hline Adjusted $\mathrm{R}^{2}$ & 0.085 & 0.255 & 0.279 & 0.281 & 0.277 \\
\hline F Statistic & $5.25 * * *$ & $14.26 * * *$ & $14.24 * * *$ & $12.94 * * *$ & $12.67 * * *$ \\
\hline
\end{tabular}

GEN gender, SEN seniority, SCI science, $L A M$ life science, agriculture and medical science, ENG engineering, $H S$ humanities and social science, $P C E$ previous commercialization experience, EIC entrepreneurial identity centrality, SIC scientific identity centrality, UEM university entrepreneurial mission (LAM omitted because of collinearity)

$\mathrm{N}=275 ; * p<0.1, * * p<0.05, * * * p<0.01$

\section{Findings}

To test our hypotheses, we performed hierarchical OLS regression using Stata 14.0. The results of the three entrepreneurial intentions (SOI, PLI, and CCI) as dependent variables are presented in Tables 5, 6, and 7, respectively. For each table, we present five models.

In Model 1, we included the control variables. While in Model 2, we introduced the identity centrality variables to test $\mathrm{H} 1$ and $\mathrm{H} 2$. In Model 3, we introduced the interaction variable to examine the interaction between entrepreneurial identity centrality and scientific identity centrality. The moderating effect of university entrepreneurial mission on identity centralities (H4a and $\mathrm{H} 4 \mathrm{~b}$ ) were tested in Model 4 and Model 5. In order to confirm the 
Table 6 Regression results with patenting and licensing intention as a dependent variable

\begin{tabular}{|c|c|c|c|c|c|}
\hline Variables & Model 1 & Model 2 & Model 3 & Model 4 & Model 5 \\
\hline$G E N$ & $\begin{array}{l}0.079 \\
(0.127)\end{array}$ & $\begin{array}{l}0.032 \\
(0.111)\end{array}$ & $\begin{array}{l}0.038 \\
(0.111)\end{array}$ & $\begin{array}{l}0.177 \\
(0.112)\end{array}$ & $\begin{array}{l}0.019 \\
(0.112)\end{array}$ \\
\hline SEN & $\begin{array}{l}-0.087 \\
(0.128)\end{array}$ & $\begin{array}{l}0.027 \\
(0.113)\end{array}$ & $\begin{array}{l}0.026 \\
(0.113)\end{array}$ & $\begin{array}{l}0.037 \\
(0.113)\end{array}$ & $\begin{array}{l}0.043 \\
(0.114)\end{array}$ \\
\hline$S C I$ & $\begin{array}{l}-0.008 \\
(0.250)\end{array}$ & $\begin{array}{l}0.127 \\
(0.218)\end{array}$ & $\begin{array}{l}0.142 \\
(0.220)\end{array}$ & $\begin{array}{l}0.120 \\
(0.222)\end{array}$ & $\begin{array}{l}0.106 \\
(0.220)\end{array}$ \\
\hline$L A M$ & Omitted & Omitted & Omitted & Omitted & Omitted \\
\hline$E N G$ & $\begin{array}{l}0.398 * * \\
(0.192)\end{array}$ & $\begin{array}{l}0.407 * * \\
(0.168)\end{array}$ & $\begin{array}{l}0.411 * * \\
(0.168)\end{array}$ & $\begin{array}{l}0.414^{* *} \\
(0.170)\end{array}$ & $\begin{array}{l}0.404 * * \\
(0.168)\end{array}$ \\
\hline$H S$ & $\begin{array}{l}-0.446^{* *} \\
(0.207)\end{array}$ & $\begin{array}{l}-0.333 * \\
(0.181)\end{array}$ & $\begin{array}{l}-0.329 * \\
(0.181)\end{array}$ & $\begin{array}{l}-0.333 * \\
(0.182)\end{array}$ & $\begin{array}{l}-0.336 \\
(0.182)\end{array}$ \\
\hline$P C E$ & $\begin{array}{l}0.788 * * * \\
(0.133)\end{array}$ & $\begin{array}{l}0.539 * * * \\
(0.118)\end{array}$ & $\begin{array}{l}0.548 * * * \\
(0.119)\end{array}$ & $\begin{array}{l}0.515^{* * *} * \\
(0.120)\end{array}$ & $\begin{array}{l}0.518 * * * \\
(0.120)\end{array}$ \\
\hline$E I C$ & & $\begin{array}{l}0.689 * * * \\
(0.079)\end{array}$ & $\begin{array}{l}0.618 * * * \\
(0.208)\end{array}$ & $\begin{array}{l}0.762 * * * \\
(0.222)\end{array}$ & $\begin{array}{l}0.672 * * \\
(0.081)\end{array}$ \\
\hline$S I C$ & & $\begin{array}{l}0.072 \\
(0.055)\end{array}$ & $\begin{array}{l}0.202 \\
(0.201)\end{array}$ & $\begin{array}{l}0.062 \\
(0.057)\end{array}$ & $\begin{array}{l}-0.012 \\
(0.180)\end{array}$ \\
\hline$U E M$ & & & & $\begin{array}{l}0.148 * \\
(0.085)\end{array}$ & $\begin{array}{l}0.124 * \\
(0.066)\end{array}$ \\
\hline$E I C * S I C$ & & & $\begin{array}{l}0.228 * \\
(0.129)\end{array}$ & & \\
\hline$E I C^{*} U E M$ & & & & $\begin{array}{l}-0.333 \\
(0.077)\end{array}$ & \\
\hline$S I C * U E M$ & & & & & $\begin{array}{l}0.027 \\
(0.058)\end{array}$ \\
\hline Constant & $\begin{array}{l}2.271 * * * \\
(0.233)\end{array}$ & $\begin{array}{l}0.436 * \\
(0.244)\end{array}$ & $\begin{array}{l}2.104 * * \\
(0.047)\end{array}$ & $\begin{array}{l}0.105 \\
(0.063)\end{array}$ & $\begin{array}{l}0.539 * \\
(0.313)\end{array}$ \\
\hline $\mathrm{R}^{2}$ & 0.297 & 0.471 & 0.476 & 0.478 & 0.474 \\
\hline Adjusted $\mathrm{R}^{2}$ & 0.281 & 0.455 & 0.458 & 0.460 & 0.456 \\
\hline F Statistic & $18.83 * * *$ & $29.58 * * *$ & $26.28 * * *$ & $26.38 * * *$ & $26.50 * * *$ \\
\hline
\end{tabular}

GEN gender, SEN seniority, SCI science, $L A M$ life science, agriculture and medical science, ENG engineering, $H S$ humanities and social science, $P C E$ previous commercialization experience, EIC entrepreneurial identity centrality, SIC scientific identity centrality, UEM university entrepreneurial mission. (LAM omitted because of collinearity)

$\mathrm{N}=275 ; * p<0.1, * * p<0.05, * * * p<0.01$

issues of multicollinearity, we calculated the variance inflation factor (VIF) and the overall result shows that all VIFs were ranging between 1.03 and 2.54 which below the acceptable value (VIFs <5). The results suggest that multicollinearity is not a problem in our study.

In Model 1, we assessed the effect of demographic variables on the intention to conduct different research commercialisation activities. The findings confirm the common arguments in most studies (Abreu and Grinevich 2017; Goel, Göktepe-Hultén, and Ram 2015) that male academic scientists are more likely to engage in spin-off creation and other activities, such as contracting research and consultation, but there is no significant gender gap in patenting and licensing intention. Moreover, the findings show that academic seniority does not significantly influence academic entrepreneurial intention. This may because junior academic scientists are more ambitious and have positive entrepreneurial attitude 
Table 7 Regression results with contracting research \& consulting intention as a dependent variable

\begin{tabular}{|c|c|c|c|c|c|}
\hline Variables & Model 1 & Model 2 & Model 3 & Model 4 & Model5 \\
\hline$G E N$ & $\begin{array}{l}-0.169^{*} \\
(0.090)\end{array}$ & $\begin{array}{l}-0.233^{* *} \\
(0.104)\end{array}$ & $\begin{array}{l}-0.235^{* *} \\
(0.105)\end{array}$ & $\begin{array}{l}-0.234^{* *} \\
(0.106)\end{array}$ & $\begin{array}{l}-0.233 \text { ** } \\
(0.106)\end{array}$ \\
\hline SEN & $\begin{array}{l}-0.128 \\
(0.124)\end{array}$ & $\begin{array}{l}0.005 \\
(0.106)\end{array}$ & $\begin{array}{l}0.005 \\
(0.107)\end{array}$ & $\begin{array}{l}0.008 \\
(0.107)\end{array}$ & $\begin{array}{l}0.020 \\
(0.107)\end{array}$ \\
\hline$S C I$ & $\begin{array}{l}-0.239 \\
(0.243)\end{array}$ & $\begin{array}{l}-0.107 \\
(0.206)\end{array}$ & $\begin{array}{l}-0.109 \\
(0.207)\end{array}$ & $\begin{array}{l}-0.067 \\
(0.209)\end{array}$ & $\begin{array}{l}-0.111 \\
(0.207)\end{array}$ \\
\hline$L A M$ & Omitted & Omitted & Omitted & Omitted & Omitted \\
\hline$E N G$ & $\begin{array}{l}0.190 \\
(1.87)\end{array}$ & $\begin{array}{l}0.208 \\
(0.158)\end{array}$ & $\begin{array}{l}0.207 \\
(0.159)\end{array}$ & $\begin{array}{l}0.239 \\
(0.159)\end{array}$ & $\begin{array}{l}0.207 \\
(0.158)\end{array}$ \\
\hline$H S$ & $\begin{array}{l}0.008 \\
(0.201)\end{array}$ & $\begin{array}{l}0.085 \\
(0.171)\end{array}$ & $\begin{array}{l}0.084 \\
(0.171)\end{array}$ & $\begin{array}{l}0.103 \\
(0.172)\end{array}$ & $\begin{array}{l}0.092 \\
(0.172)\end{array}$ \\
\hline$P C E$ & $\begin{array}{l}0.898^{* * * *} \\
(0.129)\end{array}$ & $\begin{array}{l}0.642 * * * \\
(0.111)\end{array}$ & $\begin{array}{l}0.640 * * * \\
(0.113)\end{array}$ & $\begin{array}{l}0.629 * * * \\
(0.113)\end{array}$ & $\begin{array}{l}0.638 * * * \\
(0.113)\end{array}$ \\
\hline$E I C$ & & $\begin{array}{l}0.768 * * * \\
(0.075)\end{array}$ & $\begin{array}{l}0.739 * * * \\
(0.196)\end{array}$ & $\begin{array}{l}1.045^{* * *} * \\
(0.209)\end{array}$ & $\begin{array}{l}0.764 * * * \\
(0.076)\end{array}$ \\
\hline$S I C$ & & $\begin{array}{l}-0.134 * * \\
(0.057)\end{array}$ & $\begin{array}{l}-0.164 * * \\
(0.070)\end{array}$ & $\begin{array}{l}-0.133^{* *} \\
(0.051)\end{array}$ & $\begin{array}{l}-0.199 * \\
(0.102)\end{array}$ \\
\hline$U E M$ & & & & $\begin{array}{l}0.280^{* *} * \\
(0.112)\end{array}$ & $\begin{array}{l}0.256^{* *} \\
(0.108)\end{array}$ \\
\hline$E I C * S I C$ & & & $\begin{array}{l}0.012 \\
(0.072)\end{array}$ & & \\
\hline$E I C^{*} U E M$ & & & & $\begin{array}{l}-0.104 \\
(0.072)\end{array}$ & \\
\hline$S I C * U E M$ & & & & & $\begin{array}{l}0.055 \\
(0.055)\end{array}$ \\
\hline Constant & $\begin{array}{l}2.773 * * * \\
(0.952)\end{array}$ & $\begin{array}{l}1.032 * * \\
(0.276)\end{array}$ & $\begin{array}{l}1.109 * * \\
(0.542)\end{array}$ & $\begin{array}{l}0.283 * \\
(0.146)\end{array}$ & $\begin{array}{l}1.408 * * * \\
(0.499)\end{array}$ \\
\hline $\mathrm{R}^{2}$ & 0.229 & 0.454 & 0.459 & 0.454 & 0.455 \\
\hline Adjusted $\mathrm{R}^{2}$ & 0.212 & 0.437 & 0.441 & 0.435 & 0.436 \\
\hline F Statistic & $13.29 * * *$ & $27.61 * * *$ & $24.45 * * *$ & $24.46^{* * *}$ & $24.55 * * *$ \\
\hline
\end{tabular}

GEN gender, SEN seniority, SCI science, $L A M$ life science, agriculture and medical science, ENG engineering, $H S$ humanities and social science, $P C E$ previous commercialization experience, EIC entrepreneurial identity centrality, SIC scientific identity centrality, UEM university entrepreneurial mission. (LAM omitted because of collinearity)

$\mathrm{N}=275 ; * p<0.1, * * p<0.05, * * * p<0.01$

while the senior academic scientists are more reluctant to engage in entrepreneurial activities (Chen et al. 2016). With regard to the role of discipline in research commercialisation activities, the findings show that academic scientists with an engineering background are more active in spin-off creation and patenting and licensing activities compared to academic scientists from other disciplines, confirming previous academic entrepreneurship findings (Huyghe et al. 2015,2016). Overall, the analysis of the control variables indicate the importance of focusing on Chinese contextual factors in academic entrepreneurship research.

In Model 2, we introduced the identity centrality variables. The Adjusted $\mathrm{R}^{2}$ significantly increased for all three dependent variables (Table 5 from 0.085 to 0.255 ; Table 6 from 0.281 to 0.455 ; Table 7 from 0.212 to 0.437 ), which shows that the explanatory power 

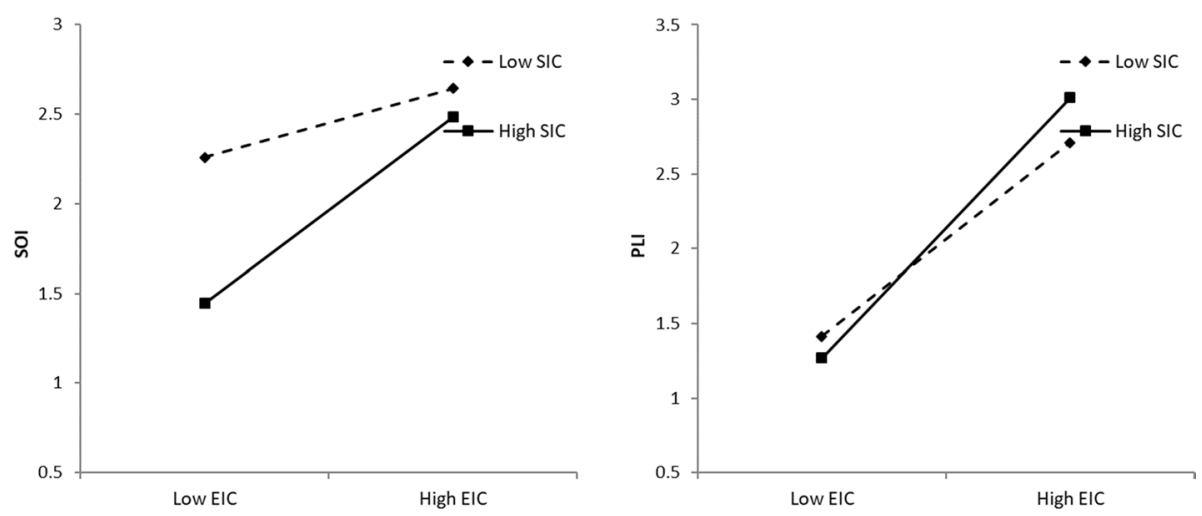

Fig. 2 The interaction between entrepreneurial and scientific identity centrality. SOI spin-offs intention, $P L I$ patenting and licensing intention, EIC entrepreneurial identity centrality, SIC scientific identity centrality

of Model 2 was improved by adding the identity centrality variables. The tables show that the coefficient of the entrepreneurial identity centrality variable is positive and significant when the variable of spin-offs intention used as dependent variable $(c=0.840, p<0.01$ in Table 5). Surprisingly the result also confirms that the entrepreneurial identity centrality has positive and significant influence on patenting and licensing intention $(c=0.689$, $p<0.01)$ and contracting research and consulting intention $(\mathrm{c}=0.768, p<0.01)$. For scientific identity centrality, the results show that the coefficient is negative and significant for both Table $5(c=-0.229, p<0.05)$ and Table $7(c=-0.134, p<0.05)$. In this case, the variable of scientific identity centrality has a negative influence on the intention to start spin-offs and to contracting research and consulting. In contrast, the coefficient for scientific identity centrality is positive but not significant $(c=0.072, p>0.1)$ where patenting and licensing intention was used as a dependent variable. Hence, we only find partial support for H1and $\mathrm{H} 2$.

We introduced Model 3 to test the interactive effects of entrepreneurial and scientific identity centrality on the three academic entrepreneurship intentions. The adjusted $\mathrm{R}^{2}$ significantly increases for all three intentions, indicating the increased explanatory power of Model 3 in Tables 5, 6, and 7. However, only for spin-off intention and patenting and licensing intention, the interactive variables $\left(E I C^{*} S I C\right)$ are positive and significant $(c=0.263, p<0.05$ in Table 5; $c=0.228, p<0.1$ in Table 6). The findings indicate that academic scientists with a high level of both scientific identity centrality and entrepreneurial identity centrality are more likely to develop strong entrepreneurial intention to create university spin-offs or engage in patenting and licensing. In the case of contracting research and consulting intentions, the coefficient is positive but not significant $(c=0.012, p>0.1$ in Table 6). Thus, we find partial support for H3. Figure 2 are plotted to illustrates the role of scientific identity centrality in moderating the relationship between entrepreneurial identity centrality with entrepreneurial intention in starting spin-offs and patenting and licensing, where the high-level means the value is one standard deviation above the average, and vice versa.

The next analysis deals with the role of university entrepreneurial mission on academic entrepreneurship intention in Model 4 and Model 5. Apparently, the coefficient of the interaction variable is positive and significant only for spin-off intention $\left(E I C^{*} U E M, \mathrm{c}=0.186\right.$, $p<0.1$; SIC $* U E M, \mathrm{c}=0.127, p<0.1$ in Table 5). The results suggest that the moderating effects of university entrepreneurial mission for the identity centrality-intention relation works 

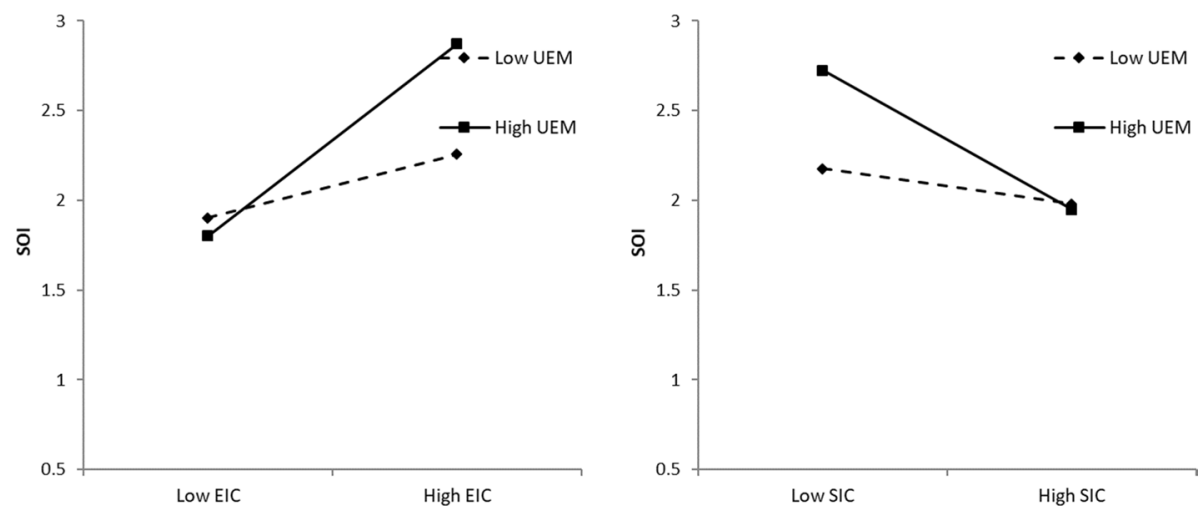

Fig. 3 The moderating effects of University entrepreneurial mission on the relation between identity centrality and spin-off intention. SOI spin-offs intention, $U E M$ university entrepreneurial mission, EIC entrepreneurial identity centrality, SIC scientific identity centrality

only for spin-off intention. Thus, H4a and $4 \mathrm{~b}$ are partially supported. Figure 3 are plotted to illustrate the interaction between identity centrality variables and the variable of university entrepreneurial mission, which shows high level of university entrepreneurial mission has a significant influence on strengthening the influence of entrepreneurial identity centrality and weakening the influence of scientific identity centrality on individual spin-off intention.

\section{Discussions and conclusion}

Motivated by the extent literature in psychological perspective on entrepreneurship, this study employs the identity theory and incorporating different types of identity centrality possessed by academic scientist and the role of university entrepreneurial mission in influencing entrepreneurial intention. While much of the work have focused on unpacking the conflict between entrepreneurial and scientific identity, our study followed the logic developed by Jain et al. (2009), Bercovitz and Feldman (2008) on the reconstruction and re-modification of individual's identity. For that reason, we hypothesized that both entrepreneurial and scientific identity are interrelated.

Related to our research questions, this study found that entrepreneurial identity centrality is critical for academic entrepreneurship by encouraging academic scientist to consider different forms of commercialisation activities. This finding supports previous studies (Abreu and Grinevich 2013; O'Kane et al. 2015) that argues the important of entrepreneurial attitude regardless the types of commercialization activities. Looking on Chinese context, the finding that entrepreneurial identity centrality has positive implication on spin-offs creation, patenting and licensing shows that current regulation does not become a barrier for commercialization activities as long as academic scientists have a strong entrepreneurial mind-set (Wu 2010). However, the study found that scientific identity was confirmed to have a negative effect on spin-offs intention. This finding shows that the conflict between entrepreneurial and scientific identity is still prevailing especially in the context of spinoff creation (Jain et al. 2009; O'Kane et al. 2015; Wu 2010). Apparently, having a strong scientific identity may force academic scientists to stay in academia or find less complex commercialization activities such as research contracting or consulting. Another barrier for 
academic scientists in China to establish spin-offs is due to the regulation on the ownership of the spin-offs (J. Wu, Zhuo, and Wu 2017).

Moreover, the interaction analysis of this study confirms the effect of entrepreneurial identity centrality is stronger for academic scientists with intentions for spin-off creating, patenting and licensing when it combines with scientific identity centrality. These findings indicate that scientific identity centrality does not merely conflict with academic scientists' intention to engage in academic entrepreneurship activities but may complement their aspiration to participate in entrepreneurial activities. This study shows support to the work of Jain et al. (2009) and Pratt and Foreman (2000) that argue on the concept of hybrid or multiple identity. However, there is no evidence for such interaction effect on contracting research and consulting intention. in other words, academic scientists with a strong entrepreneurial identity centrality prefer to engage in creating spin-offs, patenting or licensing as a way for research commercialization. This might because the lower market perspective for contracting research and consulting especially among academic scientists with hybrid identity centrality (Guan et al. 2007). Interestingly, when scientific identity was analysed independently, the study found no evidence for the intention to commercialize research. It might be the case that academic scientists with strong scientific identity centrality prefer to stay away from academic entrepreneurship. They are more inclined to publish their work in important journals instead of engage in commercialization activities. Another explanation is because they have a little knowledge about IP protection or the benefit of research commercialization (Eesley et al. 2016).

Concerning the effect of university context, we confirmed that the impact of university entrepreneurial mission is only relevant for academic scientists with entrepreneurial identity centrality in the context of spin-offs creation. This finding not only implies the importance of university institutional context to encourage academic scientists' intention to establish start spin-offs, which have been highlighted in previous studies, but also reflects some limitation and weakness regarding to other alternative path for research commercialization such as patenting, licensing, research contracting and consulting. Although the Chinese government have enacted several laws to protect the ownership of intellectual property and to encourage new inventions to be patented, academic scientists still perceive as a barrier for research commercialization (Eesley et al. 2016). Moreover, activities such as contracting research and consulting activities is more likely to be influenced by personal social networks with industry (Wright et al. 2008), especially in Chinese "Guanxi" society. To summarise, the results of the hypotheses testing are presented in Table 8.

\subsection{Contribution and limitation}

The theoretical contributions of this study can be demonstrated in several ways. First, the study extends academic entrepreneurship research by using identity theory to examine how identity centrality influences academic scientists' intention to take part in different research commercialisation activities. Although a large body of research focuses on psychological perspectives of individual academic scientists, such as motivations (Hayter 2015; Lam 2010), cognition styles and passions (Huyghe et al. 2016), attitudes and belief (Urban and Chantson 2019), few studies provide empirical evidences on the effects of identity centrality in supporting or inhibiting activities, such as spin-off creation, patenting, licensing, research contracting and consulting. 
Table 8 Summary of the hypotheses testing

\begin{tabular}{|c|c|c|}
\hline & Hypotheses & Findings \\
\hline \multirow[t]{3}{*}{ H1 } & The positive relationship between $E I C$ and $S O I$ & Supported \\
\hline & No positive relationship between $E I C$ and $P L I$ & Rejected \\
\hline & No positive relationship between $E I C$ and $C C I$ & Rejected \\
\hline \multirow[t]{3}{*}{$\mathrm{H} 2$} & The negative relationship between $S I C$ and $S O I$ & Supported \\
\hline & The positive relationship between $S I C$ and $P L I$ & Rejected \\
\hline & The positive relationship between $S I C$ and $C C I$ & Rejected \\
\hline \multirow[t]{3}{*}{ H3 } & The moderating effect of SIC on the relationship between $E I C$ and $S O I$ (positive) & Supported \\
\hline & The moderating effect of SIC on the relationship between $E I C$ and $P L I$ (positive) & Supported \\
\hline & The moderating effect of SIC on the relationship between $E I C$ and $C C I$ (positive) & Rejected \\
\hline \multirow[t]{3}{*}{$\mathrm{H} 4 \mathrm{a}$} & The moderating effect of UEM on the relationship between $E I C$ and $S O I$ (positive) & Supported \\
\hline & The moderating effect of UEM on the relationship between $E I C$ and $P L I$ (negative) & Rejected \\
\hline & The moderating effect of UEM on the relationship between $E I C$ and $C C I$ (negative) & Rejected \\
\hline \multirow[t]{3}{*}{$\mathrm{H} 4 \mathrm{~b}$} & The moderating effect of UEM on the relationship between $S I C$ and $S O I$ (negative) & Supported \\
\hline & The moderating effect of UEM on the relationship between $S I C$ and $P L I$ (positive) & Rejected \\
\hline & The moderating effect of UEM on the relationship between $S I C$ and $C C I$ (positive) & Rejected \\
\hline
\end{tabular}

EIC entrepreneurial identity centrality, SIC scientific identity centrality, SOI spin-offs intention, $P L I$ patenting and licensing intention, $C C I$ contract research and consulting intention, $U E M$ university entrepreneurial mission

Second, our study enriches the academic entrepreneurship literature by revealing an intricate relationship between entrepreneurial and scientific identity centrality. The findings suggest that both identity centralities play a role in endorsing research commercialisation activities. This finding presents a new perspective in explaining role conflicts in academic entrepreneurship (Zou et al. 2019), and how to balance the hybrid role identities in identity hierarchy (Jain et al. 2009; O'Kane et al. 2019). As the finding has shown, the interactive effect of both identity centrality offers a stimulating opening for further investigation on the new emerging concept, such as entrepreneurship as a practice. As we perceive entrepreneurship as an unfolding of everyday practices, it is believed that entrepreneurs carry patterns of behaviour and routines at an individual level, social level and the activities that happen in these two levels. In the context of starting spin-offs, the finding shows that academic entrepreneurs do not only rely consciously on their scientific identity centrality but also on their entrepreneurial mindset, knowledge, social influence and support. Overall, the study provides a new theoretical insight on how to create a balance between an entrepreneurial and scientific mindset and to encourage more academic scientists to engage in entrepreneurial activities.

Lastly, the study makes a contribution by confirming the presence of moderating effects of institutional mechanism such as university entrepreneurship mission on the relationship between academic scientists' identity and their intention for entrepreneurship. More specifically, this study found that the university mission to support entrepreneurship influences academic scientists' willingness and ability to commercialise research through spinoffs. This finding enriches not only the current debate in the literature especially on the importance of external and contextual factors in supporting entrepreneurship (O'Kane et al. 2019; Perkmann et al. 2013; Zhao et al. 2020), but also opens up a new avenue for discussion whether the existing policies have been focusing too heavily on spin-offs and neglecting other forms of commercialization activities. This situation is highly challenging 
for university managers such as TTOs, heads of department and research group leaders to develop policies that are more specific and tailored to the characteristics and needs of academic scientists.

Moreover, the results of our study indeed have some practical recommendation for policy makers. First, the study provides insights of role of entrepreneurial and scientific identity in motivating academic scientists to participate in certain entrepreneurial activities. Based on the finding of this study, some proactive policies could be developed to encourage academic scientists to pursue different mechanism of research commercialization from a rather complex activity such as spin-off creation to informal activities such as take part in contract research or consultation. Consequently, technology transfer office at Chinese university needs to redefine their roles in introducing more commercialization activities. Moreover, one of the interesting findings of this study is that even though scientific identity centrality is negatively related to the intention to creating university spin-offs, when academic scientists exhibit low entrepreneurial identity centrality. The impact of interaction between entrepreneurial and scientific identity centrality strengthens their intentions on both spin-off intention and patenting and licensing intention. This result implies that having scientific identity centrality may benefit academic entrepreneurship when entrepreneurial identity centrality is strong enough to balance the impact of scientific identity centrality. To this end, policies to nurture their entrepreneurial identity centralities should be developed to allow academic scientists to balance both scientific and entrepreneurial mindset in identifying and shaping opportunities. Given that the university mission is important for academic entrepreneurship, university managers such as TTOs officers, head department and research leaders could create a better environment and formulate incentive to encourage academic scientists to commercialise research and to manage uncertainty (O'Kane et al. 2019). More specifically, as the findings of our study suggest that the university mission can play an important role in academic entrepreneurship, universities in China may use a 'top-down' policies, either to encourage more entrepreneurial activities or provide more incentives for academic scientists to try different mechanism such as patenting, licensing, research contracting and consulting as pathways to disseminate and commercialize research. Moreover, performance evaluation and promotion criteria should be designed to include commercialization activities whereas research funding should be allocated to meet the requirements from the industry.

Our study has several limitations indicating fruitful avenues for future research. First, the measurement of this study neither involved in the actual behaviour of academic entrepreneurship nor in the level of what academic scientists do to reflect how the real identity centrality act in the realm of academic entrepreneurship. Future research is needed to investigate the deeper sense of this structure, e.g. how academic scientists allocate scarce resources like time. Second, the measurements of variables we use in this research are based on scales developed in the western literature. Although for some measures the wording was modified to avoid invalid expressions due to the cultural diversity of China and Western countries, we cannot entirely eliminate potential cultural issues (Yang 2006). Consequently, we encourage future research to develop more contextual scales for academic scientists in China. Third, the data collected in our research is cross-sectional and the findings rely on self-reported data. There is also a bias toward science and engineering school/ faculty as a source for academic entrepreneurship. In fact, many subjects in humanities and social science may produce various commercialization and entrepreneurial activities. The samples are quite limited and the data did not enable comparing the effect of role identity in different periods or assess how individual identity actually affects academic entrepreneurial intentions, considering these limitations on data collection, a longitudinal study with large 
samples is needed to address this issue. Additionally, given that both individual and organisational factors influence academic entrepreneurship (Gümüsay and Bohné 2018), comprehensive research covering such factors should be considered in future research.

Open Access This article is licensed under a Creative Commons Attribution 4.0 International License, which permits use, sharing, adaptation, distribution and reproduction in any medium or format, as long as you give appropriate credit to the original author(s) and the source, provide a link to the Creative Commons licence, and indicate if changes were made. The images or other third party material in this article are included in the article's Creative Commons licence, unless indicated otherwise in a credit line to the material. If material is not included in the article's Creative Commons licence and your intended use is not permitted by statutory regulation or exceeds the permitted use, you will need to obtain permission directly from the copyright holder. To view a copy of this licence, visit http://creativecommons.org/licenses/by/4.0/.

\section{References}

Abreu, M., \& Grinevich, V. (2013). The nature of academic entrepreneurship in the UK: Widening the focus on entrepreneurial activities. Research Policy, 42(2), 408-422.

Abreu, M., \& Grinevich, V. (2017). Gender patterns in academic entrepreneurship. Journal of Technology Transfer, 42(4), 763-794.

Acs, Z. J., Stam, E., Audretsch, D. B., \& O’Connor, A. (2017). The lineages of the entrepreneurial ecosystem approach. Small Business Economics, 49(1), 1-10.

Ajzen, I. (1991). The theory of planned behaviour. Organizational Behaviour and Human Decision Processes, 50, 179-211.

Ajzen, I. (2002). Perceived behavioral control, self-efficacy, locus of control, and the theory of planned behavior. Journal of Applied Social Psychology, 32(4), 665-683.

Ambos, T. C., Mäkelä, K., Birkinshaw, J., \& D’Este, P. (2008). When does university research get commercialized? Creating Ambidexterity In Research Institutions. Journal of Management Studies, 45(8), $1424-1447$.

Ashforth, B. (2000). Role transitions in organizational life: An identity-based perspective. London: Routledge.

Bartunek, J. M., \& Rynes, S. L. (2014). Academics and practitioners are alike and unlike. Journal of Management, 40(5), 1181-1201.

Bercovitz, J., \& Feldman, M. (2008). Academic entrepreneurs: Organizational change at the individual level. Organization Science, 19(1), 69-89.

Chen, A., Patton, D., \& Kenney, M. (2016). University technology transfer in China: A literature review and taxonomy. Journal of Technology Transfer, 41(5), 891-929.

Clarysse, B., Tartari, V. \& Salter, A. (2011). The impact of entrepreneurial capacity, experience and organizational support on academic entrepreneurship. Research Policy, 40(8), 1084-1093.

Ding, W. W., Murray, F., \& Stuart, T. E. (2013). From bench to board: gender differences in university scientists' participation in corporate scientific advisory boards. Academy of Management Journal, 56(5), 1443-1464.

Douglas, E. J., \& Fitzsimmons, J. R. (2013). Intrapreneurial Intentions versus Entrepreneurial Intentions: Distinct constructs with different antecedents. Small Business Economics, 41, 115-132.

Dunn, M. B., \& Jones, C. (2010). Institutional logics and institutional pluralism: The contestation of care and science logics in medical education, 1967-2005. Administrative Science Quarterly, 55(1), $114-149$.

Eesley, C., Li, J. B., \& Yang, D. (2016). Does Institutional change in universities influence high-tech entrepreneurship? Evidence from China's project 985. Organization Science, 27(2), 446.

Etzkowitz, H., Webster, A., Gebhardt, C., \& Terra, B. R. C. (2000). The future of the university and the university of the future: Evolution of ivory tower to entrepreneurial paradigm. Research Policy, 29(2), 313-330.

Falck, O., Heblich, S., \& Luedemann, E. (2012). Identity and entrepreneurship: Do school peers shape entrepreneurial intentions? Small Business economics, 39, 39-59.

Farmer, S. M., Tierney, P., \& Kung-Mcintyre, K. (2003). Employee creativity in Taiwan: an application of role identity theory. Academy of Management Journal, 46(5), 618-630. 
Farrell, A. M. (2010). Insufficient discriminant validity: A Comment on Bove, Pervan, Beatty, and Shiu (2009). Journal of Business Research, 63(3), 324-327.

Fenters, V., Balven, R. M., Waldman, D. A., \& Siegel, D. (2017). Identity hierarchies of academic entrepreneurs: Moving beyond dyadic comparisons. Academy of Management Proceedings, 2017(1), 13936.

Fernández-Pérez, V., Alonso-Galicia, P. E., Rodríquez-Ariza, L., del Mar, M., \& Fuentes-Fuentes. . (2015). Professional and personal social networks: A bridge to entrepreneurship for academics? European Management Journal, 33(1), 37-47.

Fornell, C., \& Larcker, D. F. (1981). Evaluating structural equation models with unobservable variables and measurement error. Journal of Marketing Research, 18(1), 39-50.

Foss, L., \& Gibson, D. V. (2015). The entrepreneurial university: Context and institutional change. London: Routledge.

Gecas, V. (1982). The self-concept. Annual Review of Sociology, 8(1), 1-33.

Goel, R. K., Göktepe-Hultén, D., \& Ram, R. (2015). Academics' entrepreneurship propensities and gender differences. Journal Technology Transfer, 40, 161-177.

Guan, J. C., et al. (2007). Technology analysis \& strategic management collaboration between industry and research institutes/universities on industrial innovation in Beijing, China. Technology Analysis \& Strategic Management, 17(3), 339-353.

Gümüsay, A. A., \& Bohné, T. M. (2018). Individual and organizational inhibitors to the development of entrepreneurial competencies in universities. Research Policy, 47(2), 363-378.

Hayter, C. S. (2015). Public or private entrepreneurship? revisiting motivations and definitions of success among academic entrepreneurs. Journal of Technology Transfer, 40(6), 1003-1015.

Hayter, C. S., Nelson, A. J., Zayed, S., \& O'Connor, A. C. (2018). Conceptualizing academic entrepreneurship ecosystems: A review, analysis and extension of the literature. Journal of Technology Transfer, 43(4), 1039-1082.

Henkel, M. (2005). Academic identity and autonomy in a changing policy environment. Higher Education, $49(1-2), 155-176$.

Hirsh, J. B., \& Kang, S. K. (2016). Mechanisms of identity conflict: Uncertainty, anxiety, and the behavioral inhibition system. Personality and Social Psychology Review, 20(3), 223-244.

Holley, A. C., \& Watson, J. (2017). Academic entrepreneurial behavior: Birds of more than one feather. Technovation, 64, 50-57.

Huyghe, A., et al. (2015). The influence of organizational culture and climate on entrepreneurial intentions among research scientists. J TechnolTransf, 40, 138-160.

Huyghe, A., Knockaert, M., \& Obschonka, M. (2016). Unraveling the 'Passion Orchestra' in academia. Journal of Business Venturing, 31(3), 344-364.

Iacobucci, D., \& Micozzi, A. (2015). How to evaluate the impact of academic spin-offs on local development: An empirical analysis of the italian case. The Journal of Technology Transfer, 40(3), 434-452.

Ibarra, H. (1999). Provisional selves: Experimenting with Image and Identity in professional adaptation. Administrative Science Quarterly, 44(4), 764.

Iorio, R., Labory, S., \& Rentocchini, F. (2017). The Importance of pro-social behaviour for the breadth and depth of knowledge transfer activities: An analysis of italian academic scientists. Research Policy, 46(2), 497-509.

Jain, S., George, G., \& Maltarich, M. (2009). Academics or entrepreneurs? Investigating role identity modification of university scientists involved in commercialization activity. Research Policy, 38(6), 922-935.

Johnson, M., Monsen, E. W., \& MacKenzie, N. G. (2017). Follow the leader or the pack? Regulatory focus and academic entrepreneurial intentions. Journal of Product Innovation Management, 34(2), 181-200.

Klemm, M., Sanderson, S., \& Luffman, G. (1991). Mission statements: Selling corporate values to employees. Long Range Planning, 24(3), 73-78.

Krueger, N. F., \& Carsrud, A. L. (1993). Entrepreneurial intentions: Applying the theory of planned behaviour. Entrepreneurship and Regional Development, 5(4), 315-330.

Krueger, N. F., Reilly, M. D., \& Carsrud, A. L. (2000). Competing models of entrepreneurial intentions. Journal of Business Venturing, 15(5), 411-432.

Lam, A. (2010). From 'Ivory Tower Traditionalists' to 'Entrepreneurial Scientists'? Social Studies of Science, 40(2), 307-340.

Leavitt, K., et al. (2012). Different hats, different obligations: plural occupational identities and situated moral judgments. Academy of Management Journal, 55(6), 1316-1333.

Liu, Y., \& Huang, Q. (2018). University capability as a micro-foundation for the triple helix model: The case of China. Technovation, 76-77, 40-50.

Lockett, A., Siegel, D., Wright, M., \& Ensley, M. D. (2005). The creation of spin-off firms at public research institutions: Managerial and policy implications. Research Policy, 34(7), 981-993. 
Mangematin, V., O’Reilly, P., \& Cunningham, J. (2014). PIs as boundary spanners, science and market shapers. Journal of Technology Transfer, 39(1), 1-10.

Marzocchi, C., Kitagawa, F., \& Sánchez-Barrioluengo, M. (2019). Evolving missions and university entrepreneurship: Academic spin-offs and graduate start-ups in the entrepreneurial society. Journal of Technology Transfer, 44(1), 167-188.

Mathias, B. D., \& Williams, D. W. (2017). The Impact of role identities on entrepreneurs' evaluation and selection of opportunities. Journal of Management, 43(3), 892-918.

Murnieks, C. Y., Michael Haynie, J., Wiltbank, R. E., \& Harting, T. (2011). 'I Like How You Think': Similarity as an interaction bias in the investor-entrepreneur dyad. Journal of Management Studies, 48(7), 1533-1561.

Murnieks, C. Y., Michael Haynie, J., Wiltbank, R. E., \& Harting, T. (2014b). Pathways of passion. Journal of Management, 40(6), 1583-1606.

Murnieks, C. Y., Mosakowski, E., \& Cardon, M. S. (2014a). Pathways of passion. Journal of Management, 40(6), 1583-1606. https://doi.org/10.1177/0149206311433855.

Navis, C., \& Glynn, M. A. (2011). Legitimate distinctiveness and the entrepreneurial identity: influence on investor judgments of new venture plausibility. Academy of Management Review, 36(3), 479-499.

Nelson, A. J. (2014). From the ivory tower to the startup garage: Organizational context and commercialization processes. Research Policy, 43(7), 1144-1156.

O'Kane, C., Mangematin, V., Geoghegan, W., \& Fitzgerald, C. (2015). University technology transfer offices: The search for identity to build legitimacy. Research Policy, 44(2), 421-437.

O'Kane, C., Zhang, J. A., Daellenbach, U., \& Davenport, S. (2019). Building entrepreneurial behaviours in academic scientists: past perspective and new initiatives. Entrepreneurial Behaviour (pp. 145-166). London: Palgrave Macmillan.

Obschonka, M., Moeller, J., \& Goethner, M. (2019). Entrepreneurial passion and personality: The case of academic entrepreneurship. Frontiers in Psychology, 9, 2697.

O'Kane, C., Mangematin, V., Zhang, J. A., \& Cunningham, J. A. (2020). How university-based principal investigators shape a hybrid role identity. Technological Forecasting and Social Change, 159, 120179.

Owen-Smith, J., \& Powell, W. W. (2001). To Patent or not: Faculty decisions and institutional success at technology transfer. Journal of Technology Transfer, 26(1-2), 99-114.

Perkmann, M., et al. (2013). Academic engagement and commercialisation: A review of the literature on university-industry relations. Research Policy, 42(2), 423-442.

Perkmann, M., King, Z., \& Pavelin, S. (2011). Engaging excellence? Effects of faculty quality on university engagement with industry. Research Policy, 40(4), 539-552.

Podsakoff, N. P. (2003). Common method biases in behavioral research: A critical review of the literature and recommended remedies. Journal of Applied Psychology, 885(879), 10-1037.

Podsakoff, P. M., MacKenzie, S. B., \& Podsakoff, N. P. (2012). Sources of method bias in social science research and recommendations on how to control it. Annual Review of Psychology, 63(1), 539-569.

Podsakoff, P. M., \& Organ, D. W. (1986). Self-reports in organizational research: Problems and prospects. Journal of Management, 12(4), 531-544.

Pratt, M. G., \& Foreman, P. O. (2000). Classifying managerial responses to multiple organizational identities. Academy of Management Review, 25(1), 18-42.

Rasmussen, E., \& Wright, M. (2015). How Can universities facilitate academic spin-offs? An entrepreneurial competency perspective. Journal of Technology Transfer, 40(5), 782-799.

Sá, E., Dias, D., \& Sá, M. J. (2018). Towards the university entrepreneurial mission: Portuguese Academics' self-perspective of their role in knowledge transfer. Journal of Further and Higher Education, 42(6), 784-796.

Schaltegger, S., \& Hörisch, J. (2017). In Search of the dominant rationale in sustainability management: Legitimacy- or profit-seeking? Journal of Business Ethics, 145(2), 259-276.

Scholten, V., Omta, O., Kemp, R., \& Elfring, T. (2015). Bridging ties and the role of research and start-up experience on the early growth of dutch academic spin-offs. Technovation, 45-46, 40-51.

Sellers, R. M., Rowley, S. A., Chavous, T. M., Shelton, J. N., \& Smith, M. A. (1997). Multidimensional inventory of black identity: A preliminary investigation of reliability and constuct validity. Journal of Personality and Social Psychology, 73(4), 805.

Siegel, D. S., \& Wright, M. (2015). Academic entrepreneurship: Time for a rethink? British Journal of Management, 26(4), 582-595.

Soetanto, D., \& Jack, S. (2016). The impact of university-based incubation support on the innovation strategy of academic spin-offs. Technovation, 50, 25-40.

Stryker, S. (1968). Identity salience and role performance: The relevance of symbolic interaction theory for family research. Journal of Marriage and the Family, 30(4), 558. 
Stryker, S., \& Serpe, R. T. (1994). Identity salience and psychological centrality: Equivalent, overlapping, or complementary concepts? Social Psychology Quarterly, 57(1), 16.

Thoits, P. A. (1986). Multiple identities: Examining gender and marital status differences in distress. American Sociological Review, 51(2), 259.

Urban, B., \& Chantson, J. (2019). Academic entrepreneurship in South Africa: Testing for entrepreneurial intentions. Journal of Technology Transfer, 44(3), 948-980.

Vohora, A., Wright, M., \& Lockett, A. (2004). Critical junctures in the development of university high-tech spinout companies. Research Policy, 33(1), 147-175.

Watson, T. J. (2009). Entrepreneurial action, identity work and the use of multiple discursive resources. International Small Business Journal: Researching Entrepreneurship, 27(3), 251-274.

Wong, N., Rindfleisch, A., \& Burroughs, J. E. (2003). Do Reverse-worded items confound measures in crosscultural consumer research? The case of the material values scale. Journal of Consumer Research, 30(1), 72-91.

Wright, M., Birley, S., \& Mosey, S. (2004). Entrepreneurship and university technology transfer. Journal of Technology Transfer, 29(3-4), 235-246.

Wright, M., Clarysse, B., Lockett, A., \& Knockaert, M. (2008). Mid-Range Universities' linkages with Industry: Knowledge types and the role of intermediaries. Research Policy, 37(8), 1205-1223.

Wu, J., Zhuo, S., \& Zefu, Wu. (2017). National innovation system, social entrepreneurship, and rural economic growth in China. Technological Forecasting and Social Change, 121, 238-250.

$\mathrm{Wu}, \mathrm{W}$. (2010). Managing and incentivizing research commercialization in chinese universities. The Journal of Technology Transfer, 35(2), 203-224.

Würmseher, M. (2017). To each his own: Matching different entrepreneurial models to the academic scientist's individual needs. Technovation, 59, 1-17.

Yang, K. S. (2006). Indigenized conceptual and empirical analyses of selected chinese psychological characteristics. International Journal of Psychology, 41(4), 298-303.

Zhao, Z., Broström, A., \& Cai, J. (2020). Promoting academic engagement: university context and individual characteristics. Journal of Technology Transfer, 45(1), 304-337.

Zou, B., Guo, J., Guo, F., Shi, Y., \& Li, Y. (2019). Who am I? The influence of social identification on academic entrepreneurs' role conflict. International Entrepreneurship and Management Journal, 15(2), 363-384.

Publisher's Note Springer Nature remains neutral with regard to jurisdictional claims in published maps and institutional affiliations. 